\title{
AN EMPIRICAL ANALYSIS OF CAPITAL STRUCTURE DETERMINANTS: EVIDENCE FROM THE INDIAN CORPORATE SECTOR
}

\author{
Gurnam Singh Rasoolpur \\ Assistant Professor, P.G. Department of Commerce \& Business Management, \\ Guru Nanak College, Sukhchainana Sahib, Phagwara, Punjab, India
}

\begin{abstract}
Existing empirical research on the determinants of capital structure has been largely restricted to the advanced countries like United States, Japan, France, U. K., Germany etc. The present paper makes an empirical attempt to study the determinants of capital structure of developing countries through a case of the Indian corporate sector by using a panel data approach. The present study, although an exploratory effort, is limited to 298 out of top 500 manufacturing firms selected on the basis of the turnover for the year 20042005 which covers the time span of eleven years commencing from 1995-96 to 2005-06. The results of the study demonstrate that that uniqueness and liquidity are the important determinants of capital structure of the Indian corporate sector during the period under study. It is also found that earning rate, cash flow coverage ratio, size (total assets), growth of assets, non-debt tax shield, dividend payout ratio and operating leverage are having a little influence on the capital structure of the Indian corporate sector during the period under study.
\end{abstract}

Keywords Leverage, Corporate Sector, Correlation, Regression Analysis

\section{INTRODUCTION}

The capital structure will be planned initially when a company is incorporated. The financial manager has also to deal with an existing capital structure. Every time when funds have to be procured, the financial manager weighs the pros and cons of various sources of finance and selects the most advantageous sources keeping in view the target capital structure. Thus, the capital structure decision is a continuous one and has to be taken whenever a firm needs additional finances. As the objective of a firm should be directed towards the maximization of the value of the firm, the capital structure or leverage decision should be examined from the point of view of its impact on the value of the firm. If the value of the firm can be effected by capital structure or financing decision, a firm would like to have a capital structure which maximizes the market value of the firm. So, the financial manager should plan an optimum capital structure for his company. The optimum capital structure is obtained when the market value per share is maximum.

Capital structure is the mix of debt, equity and preference securities that are used to finance a company's assets. Leverage is generally measured by the ratio called debt-equity ratio. This ratio indicates the relationship between the borrowed funds and owners' funds in the capital structure of a company.

"Many theories have been developed to show the relationship between capital structure and value of a firm. There are different views on how capital structure influences value of a firm. Some authors argue that there is no relationship between capital structure and the value of a firm, whereas others hold that financial leverage has a positive effect on value of a firm. There are also some who take the intermediate approach that financial leverage has a positive effect on the value of a firm that is only up to a certain point and thereafter there will be negative effect, another contention that, other things being equal, the greater the leverage, the greater the firm value. According to the net 
income approach when leverage varies, the cost of debt and the cost of equity remain unchanged. Therefore, the weighted average cost of capital declines as leverage increases and the value of the firm will increase."(Narinder \& Sharma, 2006). In theory, the capital structure may be considered irrelevant in a no-tax and frictionless world (Modigliani and Miller, 1958). But in practice, the capital structure of a firm assumes vital significance to corporate financial management as it influences both return and risk of shareholders. The choice between debt and equity to finance a firm's assets involves a trade-off between risk and return (Pandey, Chotigeat \& Ranjit, 2000). The excessive use of debt may endanger the survival of a firm, while a conservative use of debt may deprive the firm in leveraging return to equity owners. Therefore, in order to increase the advantage of debt capital and at the same time to save the firm from the financial and other risks, it is desirable to have a reasonable debt equity mix in the total capital structure. Thus, the decision regarding debt equity mix in the capital structure of a firm is of critical importance and has to be approached with a great care. More specifically, the determinants of capital structure choice in practice have been adequately studied for firms in developed capital markets (Taub, 1975; Bradley, Jarrell \& Kim, 1984; Titman \& Wessels, 1988; Allen \& Mizuno, 1983; Colombo, 2001; Ozkan, 2002; Beven \& Danbolt, 2002; Lord \& Farr, 2003). However, only a few studies for the firms in developing capital markets have been undertaken, for instance, Bhatt (1980), Venkatesan (1983), Pandey, Chotigeat \& Ranjit (2002), Garg \& Shekhar (2002), Bhaduri (2002), Narinder \& Sharma (2006) and Saravanan (2006) etc.. Therefore, to fill this void, top 500 manufacturing firms, published in Business Today, enlisted on the Bombay Stock Exchange of India, on the basis of sales turnover for the year 2004-05, are selected but due to some limitations, only 298 manufacturing firms are being examined under the present study. The study covers time span of eleven years commencing from 1995-96 to 2005-06.

The research paper is organized into four sections. Part first provides the introduction about the capital structure choices. Part second provides research methodology. Part third exhibits variables used, their definition and the expected relationship with capital structure. Part fourth presents reports and analyses the empirical results of the study. Part fifth, the concluding part, gives the summary and conclusions of the study.

\section{RESEARCH METHODOLOGY}

In the present study, the ratio of total borrowings to net worth is being used for measuring the capital structure (debt-equity ratio) of a firm. Here, borrowings include all forms of debtinterest bearing or otherwise. All secured and unsecured debt is included under total borrowings. Thus, total borrowings include debt from banks (short term as well as long term) and financial institutions, inter-corporate loans, fixed deposits from public and directors, foreign loans, loan from government, etc. Funds rose from the capital market through the issue of debt instruments such as debentures (both convertible and nonconvertible) and commercial paper are also included here while net worth includes equity share capital, preference share capital and reserve \& surpluses minus revaluation reserves \& miscellaneous expenses not written off. Preference share capital is irredeemable in nature. So, it is considered as a part of net worth. Short-term borrowings are included in the debt or total borrowings because it is observed that short-term borrowings are being used as a long-term source of finance in the Indian contest

Correlation, regression analysis and fixed effects approach to panel data are used to identify the determinants of capital structure of the Indian corporate sector. Further " $t$ " test have been carried out to check up the level of significance of regression coefficients. Durbin Watson test has also been applied to find out multicollinearity amongst the independent variables, if any, which would hamper the regression results.

Fixed effects approach to panel data has been used to establish relationship between capital structure and value of a firm because of certain advantages of this methodology over other methodologies in the corporate finance literature. Panel data controls the effects of missing or unobserved variables. It also controls the individual 
heterogeneity, the risk of obtaining biased results come down. The panel data gives more information, more variability, less collinearly among the variables, more degrees of freedom, and more efficiency than purely cross-section and time series data. The technical efficiency of the economic behavior is better studied and modeled with panel data. The panel data estimation yields more robust effects of independent variables on dependent variables than the time-series does.

In the panel data models, the unobservable effects can be accommodated using one of the two techniques. First, the unobservable effects can be included in the error term. The variance covariance matrix of the resulting non-spherical errors must be transformed to obtain consistent estimates of the standard errors. In this case, the "random effects" estimator is appropriate. However, a problem arises with the random effects estimator if the unobservable effects, which have been included in the error term, are correlated with some or all of the regressors. As a consistent alternative to the random effect estimator, a dummy variable can be included in each firm. This estimation approach is known as "fixed effects" approach and it gives consistent estimates regardless of correlation between firmspecific error component and regressors. There is a drawback of fixed effects model that it results in loss of large number of degrees of freedom. However, since we have sufficiently large panel data, this will not be a problem in our case.

\section{Model Specification:}

Assuming a linear relationship between capital structure and its determinants, the panel data model can be specified as:-

$$
\begin{aligned}
& \text { D/E it }=\boldsymbol{\alpha}+\sum_{\mathbf{i}=1}^{\mathbf{k}} \boldsymbol{\beta} \mathbf{i} \mathbf{X} \text { it }+\mathbf{U} \text { it } \\
& \mathrm{D} / \mathrm{E}_{\mathrm{it}}=\text { Capital Structure Ratio } \\
& \alpha \quad=\text { Intercept Term / Constant } \\
& \mathrm{X}_{\mathrm{it}}=\text { Determinants of Capital Structure } \\
& \beta_{\mathrm{I}}=\text { Coefficients of the Determinants of } \\
& \quad \text { Capital Structure } \\
& \mathrm{U}_{\mathrm{it}}=\text { an Error Term } \\
& \mathrm{I}=\text { Number of Factors Affecting } \\
& \mathrm{T}=\text { Time Periondent Variable } \\
& \mathrm{T} \quad
\end{aligned}
$$

Therefore, an empirical panel data corporate capital structure model based upon earning rate, cash flow coverage ratio, size (total assets), growth, liquidity, non-debt tax shield, dividend payout ratio, operating leverage and uniqueness, can be specified as

$\mathrm{D} / \mathbf{E}_{\text {it }}=\alpha+\beta_{1}$ Earning Rate $t+\beta_{2}$ Cash Flow Coverage Ratio $_{t}+\beta_{3}$ Size $_{t}+\beta_{4}$ Growth $_{t}+\beta_{5}$ Liquidity $_{t}+\beta_{6}$ Non-Debt-Tax Shield $t^{+} \beta_{7}$ Dividend Payout Ratio $t+\beta s$ Operating leverage $_{t}+\beta$. Uniqueness ${ }_{t}+U_{i t}$

\section{VARIABLES, DEFINITION \& EXPECTED RELATIONSHIP WITH CAPITAL STRUCTURE}

\section{Earning Rate}

Bhat (1980) reported that there is a negative relationship between earnings rate and leverage. Bhaduri (2002) concluded that the coefficients of profitability factor are significant in all models. In the short-term model, the coefficient of profitability factor has a negative sign, while it is positive in the long-term model. It means that as a firm's profitability increases, it relies more on long-term borrowing and in case of decrease in profitability, it relies more on short-term borrowing. Colombo (2001) revealed that the supply side considerations predict a positive relationship between debt and profits. But demand side considerations predict a negative relationship between debt and profits. Narender \& Sharma (2006), Mahakud (2006), Lord \& Farr (2003), Bevan \& Danbolt (2002), Pandey, Chotigeat \& Ranjit (2000), Rajan \& Zingales (1995), Allen \& Mizuno (1989), and Titman \& Wessels (1988) studied the relationship between earnings rate and leverage. All these researchers have established significant negative relationship between these two variables. However, Saravanan (2006), and Garg \& Shekhar (2002) established no significant relationship between these variables. However, Bradley, Jarrell \& Kim (1984), and Venkatesan (1983) made no explicit reference in their studies to the likely impact of increased profitability on debt ratios. Garg \& Shekhar (2002), Pandey, Chotigeat \& Ranjit (2000), Allen \& Mizuno (1989), Titman \& Wessels (1988), and Bhat 
(1980) used earnings before interest and taxes scaled by total assets, Bevan \& Danbolt (2002), and Rajan \& Zingales (1995) used earnings before interest, taxes and depreciation scaled by total assets, and Bhaduri (2002) and Colombo (2001) used cash flows scaled by total assets for measuring the earnings rate of a firm. In the present study, earnings before interest and taxes scaled by total assets at book value are to be used for measuring the earnings rate. This measure of profitability of a firm's assets is designed to indicate the efficiency of capital employed. The pecking order hypothesis implies that firms prefer raising capital, first from retained earnings, second from debt and third from issuing new equity (Mayers, 1984). Thus, this measure is expected to have negative relationship with the capital structure ratio.

Table 1

\section{VARIABLES, DEFINITION \& EXPECTED RELATIONSHIP WITH CAPITAL STRUCTURE}

\begin{tabular}{|c|c|c|c|}
\hline $\begin{array}{l}\text { Sr. } \\
\text { No. }\end{array}$ & Variables & Definition & $\begin{array}{l}\text { Expected } \\
\text { Relationship }\end{array}$ \\
\hline$(1)$ & Earning Rate & EBIT/Total Assets & Negative \\
\hline (2) & Cash Flow Coverage Ratio & $\begin{array}{l}\text { Profits Before Tax, Interest \& Depreciation/Total } \\
\text { Assets }\end{array}$ & Negative \\
\hline (3) & Size (Total Assets) & Logarithm of Total Assets & Positive \\
\hline (4) & Growth & $($ Assets $t-$ Assets $t-1) /($ Assets $t-1)$ & Positive \\
\hline (5) & Liquidity & Current Assets/Current Liabilities & Negative \\
\hline (6) & Non Debt Tax Shield & Depreciation/Total Assets & Negative \\
\hline (7) & Dividend Payout Ratio & Dividend Per Share/Earnings Per Share & Negative \\
\hline (8) & Operating Leverage & 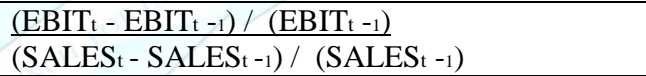 & Negative \\
\hline (9) & Uniqueness & Selling Cost/Sales & Negative \\
\hline
\end{tabular}

\section{Cash Flow Coverage Ratio}

The analysis of the ability of a firm to meet its fixed payment obligations (interest) from its cash flow is perhaps a good way to view the firm's solvency as far as debt service is concerned. Some firms may have significant differences between their earnings and funds from operations (FOP). Hence, inclusion of this variable in the empirical study would improve the effectiveness of the analysis. Venkatesan (1983) observed that cash flow coverage is found to have a higher significance as compared to debt service coverage which also confirms the earlier professed view that cash flow coverage perhaps is a more relevant measure than the traditional debt service coverage based on EBIT. He used funds from operations and interest charges over the interest charges for the year as a proxy for cash flow coverage. Bhaduri (2002) observed that the coefficients of the cash flow factor are significant in all models. In the short-term model, the cash flow coefficient has a negative sign, while it is positive in the longterm model. If cash flow can be treated as an indicator of a firm's quality and credit worthiness, then the above result indicates that low quality firms tend to depend more on short-term borrowing. However, as a firm's quality and hence, its credit worthiness increases, it relies more on long-term borrowing. Colombo (2001) indicated the existence of a "pecking-order" theory of finance with internal funds preferred over external funds. This leads to conclude that firms with a higher cash flow will be characterized by reduced leverage. He measured the cash flow as profits before tax, interest and depreciation over total assets as proxy for cash flow. In the present study, profits before tax, interest \& depreciation over total assets is used for measuring the cash flow coverage ratio and negative relationship is to 
be expected between cash flow coverage and capital structure ratio.

\section{Size}

Saravanan (2006), Mahakud (2006), Narender \& Sharma (2006), Ozkan (2002), Bevan \& Danbolt (2002), Bhaduri (2002), Garg \& Shekhar (2002), Colombo (2001), Pandey, Chotigeat \& Ranjit (2000), Titman \& Wessels (1988), and Taub (1975) concluded that corporate size is a significant determinant of firm's leverage in their empirical studies. All these researchers have established either positive or negative relationship between these two variables. On the contrary, Rajan \& Zingales (1995), Venkatesan (1983) and Bhat (1980) have concluded that the corporate size of a firm does not appear to be the determinant of the debt-equity mix in the financial structure. However, Lord \& Farr (2003), Allen \& Mizuno (1989), and Bradley, Jarrell \& Kim (1984) do not include the corporate size in their respective empirical studies. It is also observed that researchers are measuring the corporate size in different ways. Narender \& Sharma (2006), Saravanan (2006), Ozkan (2002), Bevan \& Danbolt (2002), Colombo (2001), Rajan \& Zingales (1995), Titman \& Wessels (1988), and Bhat (1980) used logarithm of sales while Bhaduri (2002) used logarithm of total assets for measuring the corporate size of a firm. But Mahakud (2006), Pandey, Chotigeat \& Ranjit (2000) Venkatesan (1983), and Taub (1975) used absolute value of total assets and/or total sales for measuring the corporate size of a firm. Over and above the logarithm of sales, Colombo (2001), and Titman \& Wessels (1988) also used employment and quit rate respectively for measuring the corporate size of a firm. In the present study, the logarithms of total assets have been used as a measure of firm's corporate size. For testing the impact of size on the capital structure of a firm, it is hypothesized that the capital structure ratio is positively influenced by the size of a firm because large or well established or diversified firm can afford to have a higher debt than a small firm due to better and easier access to capital market, and high credit rating for their debt issues.

\section{Growth}

A firm's growth rate is lower when it uses internally generated funds (retained earnings) to finance its assets. It is higher when external finances are used. When the financing needs of the firm exceed its retained earnings, it seeks debt financing. There is very little scope for debt to be mispriced. Also a debt issue prevents dilution of control. External equity appears to be the last choice. A fast growing firm needs more funds. The greater the future need for the funds, the more likely that the firm will retain earnings or issue debt. Further, when firms with growth opportunities issue more debt, it helps to resolve the agency problem i.e. using debt to the extend that it maximizes the shareholders' wealth. A firm is expected to rely on debt financing to maintain its debt ratio as its equity increases due to the large retention of earnings. Thus, the firm's debt level and growth rate are expected to have a positive relationship. However, the empirical evidence regarding the relationship between leverage (gearing) and growth opportunities is rather mixed. Ozkan (2002), Bevan \& Danbolt (2002), Rajan \& Zingales (1995) and Barclay (1995) found negative significant relationship and Bhaduri (2002), and Pandey, Chotigeat \& Ranjit (2000) found positive significant relationship between leverage and growth rate. On the contrary, Colombo (2001), Titman \& Wessels (1988), Venkatesan (1983), Bhat (1980), and TSRWB (1974) for short-term borrowings, found insignificant relationship between leverage and growth rate. However, Garg \& Shekhar (2002), Allen \& Mizuno (1989), and Bradley, Jarrel \& Kim (1984) provided little importance to this variable in their respective empirical studies. Different researchers used different methods for measuring the growth rate. Bhaduri (2002) and Titman \& Wessels (1988) used (i) capital expenditure to total assets, and (ii) the growth of total assets for measuring the growth attitude in their studies. Ozkan (2002) and Bevan \& Danbolt (2002) used market to book, i.e. book value of total assets minus book value of equity plus market value of equity over book value of total assets, for measuring this attribute. Bhat (1980) used the following method for measuring the growth rate of total assets; 


$$
\mathrm{G}_{\mathrm{i}}=\sqrt[n]{\frac{(\text { Total Assets } \mathrm{i}) \mathrm{n}}{\text { (Total Assets i)o }}}-1
$$

Where Gi is the annual compound growth rate of the ith firm and $n$ is equal to the period under study. Venkatesan (1983) used a ratio of the percentage growth in total assets to the percentage growth in funds from operation for measuring the growth rate which is as follows

$$
\mathrm{GR}_{\mathrm{t}}=\frac{\text { (Total Assets) } \mathrm{t}-\mathrm{o} / \text { (Total Assets)o }}{\text { (Funds from Operation) } \mathrm{t}-\mathrm{o} / \text { (Funds from Operations)o }}
$$

It was however, felt that the growth in assets as a proportion of the growth in the firm's cash flow from operations (vice-versa could also be used) represented the combined efforts of both asset growth and earnings growth. Annual percentage increase in assets is taken as a measure of growth in the present study which is represented by (Assets $\mathrm{t}-$ Assets $\mathrm{t}-1$ ) / (Assets $\mathrm{t}-1$ ).

\section{Liquidity}

Liquidity refers to the continuous ability of a firm to meet its current obligations as and when these become due. It is measured by the ratio of total of current assets to total of current liabilities. Narinder and Sharma (2006) empirically observed that coefficients of liquidity are highly significant in total debt model, long term debt model and short term debt model. These are positive in first two models and negative in last model. Gupta (1969) found that liquidity ratios rise with an increase in the size of the corporation but they fall with the growth rates in his empirical work. Liquid firms will use more equity capital in their capital structure. Their cash position and overall liquidity enable them to pay required rate of return to the equity shareholders. If illiquid firms are unable to pay required rate of return to the equity shareholders, then the firms will have to face serious problems while going into capital market for equity issues. Liquidity is a prerequisite for the very survival of a firm. Illiquidity may threaten the solvency of a firm and cause greater risk of cash shortage and stock-out. Therefore, the illiquid firms have to raise money from capital market through debt. Consequently, the illiquid firms will use more amount of debt in their capital structure. It is expected that liquidity has negative relationship with capital structure ratio in the present study.

\section{Non Debt Tax Shield}

Firms can use depreciation, carry forward losses etc. to shield taxes. Depreciation calculated as per the income tax rules, is, however, a deductible expense for computing taxes. So, it reduces the firm's tax liability. This implies that those firms that have larger non-debt tax shields would employ low debt i.e. there should be a negative relationship between the leverage and the nondebt tax shield. Narinder and Sharma (2006) found a positive and significant relationship between them. They further observed that the firms are not utilizing debt to pay less tax. They used depreciation over total assets to measure the non-debt tax shield. Bradley, Jarrell and Kim's (1984) found a significant positive relationship between leverage and the level of non-debt tax shields. They used to sum of annual depreciation plus investment tax credits divided by the sum of annual earnings before interest, depreciation and taxes for measuring the non-debt tax shield. Titman \& Wessels (1988) found that non-debt tax shield attribute is not a statistically significant variable for determining capital structure of a firm. They used three proxies i.e. a direct estimate of investment non-debt tax shield scaled by total assets, tax credits scaled by total assets and depreciation scaled by total assets for measuring the non-debt tax shield attribute. Allen \& Mizuno (1989) also found negative but insignificant coefficient for the non-debt tax shield in their empirical study. In the present study, depreciation divided by total assets is to be used for measuring the non-debt tax shield. It is expected that negative relationship should exist between the non-debt tax shield and capital structure ratio.

\section{Dividend Payout Ratio}

This variable has been used to examine the influence of dividend policy on financing decision. Allen \& Mizuno (1989) has found that dividend payout ratio has insignificant relation with leverage. However, Bhat (1980) has found that there is a negative relationship between dividend payout and leverage ratio, though the cause-and-effect relationship between them is not clear. The firms with high leverage ratio appear to distribute lesser proportion of their earnings available for equity shareholders possibly because of their dividend stabilization policy. The high 
leverage cause a high variation is earnings available to equity holders. Consequently, firms with high degree of earning volatility will probably distribute a lower percentage of earnings in order to avoid the necessity of reducing dividends in tough years. Further, the dividend policy of a firm reflects the managements perception regarding the uncertainty associated with future earnings. Therefore, the firms paying high dividend payout will employ low leverage. In the present study, the ratio of dividend per share over earnings per share is to be used for measuring dividend payout of a firm. Negative relationship is to be expected between dividend payout and the capital structure ratio during the study period.

\section{Operating Leverage}

Operating leverage refers to the extent to which a firm has used fixed operating costs for running its operations. A firm will not have operating leverage if its ratio of fixed costs to total costs is nil. Operating leverage affects a firm's operating profits (EBIT). It accentuates fluctuations (increases or decreases) in the firm's operating profits due to changes in quantity sold/revenues. Operating profits of a highly leveraged (operating) firm would increase at a faster rate for any given increase in sales/revenues. However, if sales fall, the firm with a high operating leverage would suffer more loss than the firm with no or low operating leverage. Higher levels of risks are attached to higher degrees of leverage. With higher operating leverage, a given uncertainty in revenue translates into higher uncertainty in profits before interest and taxes. So, higher the operating leverage, higher the variability of operating profits for any given variability of sales. Thus, a firm with higher operating leverage is more risky. Consequently, a firm will not employ more amount of debt in its capital structure. There are several proxies for measuring operating leverage i.e. the ratio of net fixed assets to total assets, the ratio of the average of net fixed assets in the current and preceding four years to the average of total assets over the same period defined as the FA/TA, the ratio of fixed to variable operating cost etc. The first two measures even according to the authors themselves are flawed. Ferri \& Jones (1979), Bhat (1980) and
Venkatesan (1983) have used a traditional measure of operating leverage which is simply the percentage change in EBIT as a proportionate percentage change in sales. Bhat (1980) has found that operating leverage has insignificant relation with financial leverage. While Venkatesan (1983) has found that it has significant relation with financial leverage. In the present study, the percentage change in EBIT as a proportionate percentage change in sales is being used for measuring operating leverage. Negative relationship is to be expected between operating leverage and the capital structure ratio during the study period.

\section{Uniqueness}

Firms can create uniqueness/intangible assets through specialization in research \& development efforts, marketing etc. Uniqueness may result into specialized skills of workers and suppliers, and supply of unique products or services to customers. A firm's R \& D expenditure over sales, selling \& advertising expenses over sales, and quit rates, the percentage of the industry's total work force that voluntarily left their jobs in the sample period are used as proxy for the firms' uniqueness or intangible assets (Titman \& Wessels, 1988). They found that debt levels are negatively related with uniqueness. Bhaduri (2002) also evidenced the same results with the first two proxies. Pandey, Chotigeat \& Ranjit (2000) showed that the Thai listed manufacturing companies, as a whole, are experiencing a weak positive relationship between selling \& administration expenses and debt. Advertising, research \& development expenses over net sales ratio has been as a proxy for uniqueness by Bradley, Jarrell \& Kim (1984) in their study. They found that there exists inverse relationship between uniqueness and leverage. In the present study, ratio of selling cost over sales is used for measuring uniqueness of a firm. Information regarding research \& development and intangible assets is asymmetric. Therefore, these are not considered in the present study. Higher uniqueness means higher outflows of cash for creating specialization in marketing. Consequently, the firms can't afford more amount of debt in their capital structure due to the risk of fixed interest commitments and repayment of 
principal amount. It shows that due to higher uniqueness, firms are using lesser amount of debt for financing purposes. Secondly, a firm that accumulates more uniqueness may have low collateral value. Negative relationship is to be hypothesized between uniqueness factor and capital structure ratio during the period under study.

\section{EMPIRICAL RESULTS}

Table 2 shows that correlation matrix of independent variables during the study period. All the correlation coefficients are less than 0.40 (except the correlation coefficient between earning rate and Cash flow coverage ratio i.e. .97) which means the there is no severe problem multicollinearity in this model. Cash flow coverage ratio and earning rate are negatively associated to the capital structure during the period under study. However these two variables are positively associated to each other. These two variables are also negatively associated to the size variable during the period under study. However size is positively associated to the capital structure during the period under study. Liquidity Ratio is negatively associated to the capital structure. However this variable is also negatively associated to the size variable but positively associated to cash flow coverage ratio, uniqueness, earning rate and growth of assets during the study period. Growth of assets, nondebt tax shield and dividend payout ratio are negatively associated to the capital structure during the study period. Uniqueness and operating leverage ratio are positively associated to the capital structure during the period under study.

\section{Liquidity}

It is documented from the analysis that a negative relationship exists between liquidity and capital structure ratio during the period under study. The coefficient is significant at 5\% level of significance. The findings are consistent with theoretically predicted hypothesis as well as earlier empirical work of Narinder and Sharma

Table 2: Correlation Matrix

\begin{tabular}{|c|c|c|c|c|c|c|c|c|c|c|}
\hline Variables & 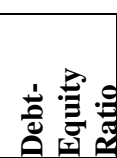 & $\stackrel{\mathscr{n}}{\pi}$ & 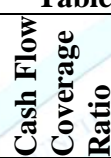 & $\stackrel{\mathscr{\Xi}}{\sigma}$ & 茎 & 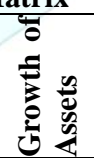 & 氠 & 亮 & 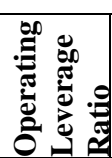 & 总 \\
\hline $\begin{array}{l}\text { Debt-equity } \\
\text { Ratio }\end{array}$ & 1 & & & & & & & & & \\
\hline Size & .0881 & 1 & & & & & & & & \\
\hline $\begin{array}{l}\text { Cash Flow } \\
\text { Coverage } \\
\text { Ratio }\end{array}$ & -.2283 & -.1398 & 1 & & & & & & & \\
\hline Uniqueness & .0048 & .1164 & -.003 & 1 & & & & & & \\
\hline $\begin{array}{l}\text { Earning } \\
\text { Rate }\end{array}$ & -.2330 & -.1307 & .974 & .0249 & 1 & & & & & \\
\hline $\begin{array}{l}\text { Growth of } \\
\text { Assets }\end{array}$ & -.0215 & .0054 & .0704 & -.040 & .1084 & 1 & & & & \\
\hline $\begin{array}{l}\text { Liquidity } \\
\text { Ratio }\end{array}$ & -.1539 & -.0305 & .2151 & .0483 & .2447 & .1157 & 1 & & & \\
\hline $\begin{array}{l}\text { Non-Debt } \\
\text { Tax Shield }\end{array}$ & -.0117 & -.0592 & .2487 & -.122 & .0256 & -.1548 & -.0989 & 1 & & \\
\hline $\begin{array}{l}\text { Operating } \\
\text { Leverage } \\
\text { Ratio }\end{array}$ & .0035 & .0113 & .0647 & -.019 & .0620 & .0109 & .0166 & .0207 & 1 & \\
\hline $\begin{array}{l}\text { Dividend } \\
\text { Payout Ratio }\end{array}$ & -.0108 & .0131 & .0031 & .0267 & .0004 & -.0138 & .0938 & .0121 & -.004 & 1 \\
\hline
\end{tabular}


Table 3-Determinants of Capital Structure where Debt-Equity Ratio is Dependent Variable (Fixed Effect Firm Model)

\begin{tabular}{|l|c|c|c|c|}
\hline Variables & B Coefficients & Standard Error & t-Statistic & Probability \\
\hline Constant & 2.045486 & 0.565916 & 3.614469 & 0.0003 \\
\hline Earning Rate & -117.8660 & 166.8941 & -0.706232 & 0.4801 \\
\hline Cash Flow Coverage Ratio & 112.1526 & 166.8754 & 0.672074 & 0.5016 \\
\hline Size (Total Assets) & 0.079675 & 0.088216 & 0.903186 & 0.3665 \\
\hline Growth of Assets & -0.130306 & 0.127188 & -1.024516 & 0.3057 \\
\hline Liquidity* & -0.144072 & 0.069878 & -2.061777 & 0.0393 \\
\hline Non-Debt Tax Shield & -117.6890 & 166.9517 & -0.704928 & 0.4809 \\
\hline Dividend Payout Ratio & 0.006306 & 0.020564 & 0.306670 & 0.7591 \\
\hline Operating Leverage & $4.35 \mathrm{E}-05$ & $4.94 \mathrm{E}-05$ & 0.881540 & 0.3781 \\
\hline Uniqueness** & -2.780009 & 1.648751 & -1.686130 & 0.0919 \\
\hline \multicolumn{4}{|l|}{$* *$ shows 10\% level of significance } \\
\hline
\end{tabular}

Table 4 -Effects Specification

\begin{tabular}{|l|l|l|l|}
\hline \multicolumn{3}{|c|}{ Cross-Section Fixed (Dummy Variables) } & \\
\hline R-Square & 0.460301 & Mean Dependent Variance & 1.204052 \\
\hline Adjusted R-Square & 0.396191 & S.D. Dependent Variance & 2.531091 \\
\hline S.E. of Regression & 1.966788 & Akaike Info Criterion & 4.291105 \\
\hline Sum Squared Residue & 8564.316 & Schwarz Criterion & 4.910642 \\
\hline Log Likelihood & -5052.679 & Hannan-Quinn Criterion & 4.516127 \\
\hline F-Statistic & 7.179809 & Durbin-Watson Statistic & 1.549581 \\
\hline Prob(F-Statistic) & 0.000000 & & \\
\hline
\end{tabular}

(2006) in short term debt model, and inconsistent in total debt model and long term debt model of the same researchers. The results suggest that illiquid firms are using more amount of debt in their capital structure because illiquid firms are "'unable to pay required rate of return to the equity shareholders. These firms may face problem of under subscription of equity issue while going into the capital market. These firms may not be able to bear the floatation cost of equity issue. Thus, these firms have to raise the capital through debt. Alternatively, liquid firms are using more amount of equity in their capital structure because liquid firms are able to pay dividend to the equity shareholders. Good reputation with good liquidity will not create any problem of under subscription of equity issue for these firms. Liquidity also enables the liquid firms to bear the floatation cost of equity issue.

\section{Uniqueness}

It is observed that uniqueness has a negative relationship with the capital structure ratio during the period under study. The coefficient is significant at $10 \%$ level of significance. The results are consistent with theoretically predicted hypothesis as well as earlier empirical work of Bradley, Jarrell \& Kim (1984), Titman \& Wessels (1988) and Bhaduri (2002). However, Pandey, Chotigeat \& Ranjit (2000) showed that the Thai listed manufacturing companies, as a whole, are experiencing a weak positive relationship between selling \& administration expenses and debt. The results show that the firms incurring higher selling costs for creating uniqueness in the field of marketing are using lesser amount of debt for financing purposes in their capital structure because higher uniqueness means higher outflows of cash for creating specialization in the field of marketing. Consequently, the firms can't afford more amount of debt in their capital structure due to the risk of fixed interest commitments and repayment of principal amount. Secondly, a firm that accumulates more uniqueness may have low collateral value.

The regression coefficient of earning rate is insignificant. Similar results are shown by Saravanan (2006) and Garg \& Shekhar (2002). 
However, Narender \& Sharma (2006), Mahakud (2006), Lord \& Farr (2003), Bevan \& Danbolt (2002), Pandey, Chotigeat \& Ranjit (2000), Rajan \& Zingales (1995), Allen \& Mizuno (1989) and Titman \& Wessels (1988) have established significant negative relationship with the capital structure ratio in their empirical studies. Bhaduri (2002) and Colombo (2001) have also established significant relationship between these two variables. Saravanan (2006), Mahakud (2006), Narender \& Sharma (2006), Ozkan (2002), Bevan \&Danbolt (2002), Bhaduri (2002), Garg \& Shekhar (2002), Colombo (2001), Pandey, Chotigeat \& Ranjit (2000), Titman \& Wessels (1988), and Taub (1975) concluded that corporate size is a significant determinant of firm's leverage in their empirical studies. All these researchers have established either positive or negative relationship of size with the capital structure. On the contrary, Rajan \& Zingales (1995), Venkatesan (1983) and Bhat (1980) have concluded that the corporate size of a firm does not appear to be the determinant of the debt-equity mix in the financial structure. However, the empirical evidence regarding the relationship between leverage (gearing) and growth opportunities is rather mixed. Ozkan (2002), Bevan \& Danbolt (2002), Rajan \& Zingales (1995) and Barclay (1995) have found negative significant relationship and Bhaduri (2002), and Pandey, Chotigeat \& Ranjit (2000) have found positive significant relationship between leverage and growth rate. On the contrary, Colombo (2001), Titman \& Wessels (1988), Venkatesan (1983), Bhat (1980), and TSRWB (1974) for short-term borrowings, have found insignificant relationship between leverage and growth rate. However, Garg \& Shekhar (2002), Allen \& Mizuno (1989), and Bradley, Jarrel \& Kim (1984) have provided little importance to this variable in their respective empirical studies. Bradley, Jarrell and Kim's (1984) and Narinder and Sharma (2006) have found a significant positive relationship between leverage and the level of non-debt tax shields. Titman \& Wessels (1988) and Allen \& Mizuno (1989) have found that nondebt tax shield attribute is not a statistically significant variable for determining capital structure of a firm. Allen \& Mizuno (1989) has found that dividend payout ratio has insignificant relation with leverage. However, Bhat (1980) has found that there is a negative relationship between dividend payout and leverage ratio. Similarly, Bhat (1980) has found that operating leverage has insignificant relation with financial leverage. However, Venkatesan (1983) has found that it has significant relation with financial leverage. While the regression coefficients of earning rate, cash flow coverage ratio, size (total assets), growth of assets, non-debt tax shield, dividend payout ratio and operating leverage are insignificant in the present study. It means that these variables are not the determinants of capital structure of the Indian corporate sector during study period. It is observed that uniqueness and liquidity have a negative relationship with the capital structure during study period. These two variables have played a significant role in determining the capital structure of the Indian corporate sector during study period.

\section{CONCLUSIONS}

This study is the maiden attempt in developing countries, especially in India in the context of the country's ongoing economic and financial market oriented reforms since 1990. Now, the financial liberalization has changed the operating environment of firms, by giving more flexibility to Indian firms in choosing their capital structure. Prior to this period India was considered as a bank oriented system. However, existing studies on the capital structure issue in India (cited earlier) have been conducted in the backdrop of strongly regulated regime of the pre-reform period. Now, the present study is of post-reform period.

Capital structure and its determinants has been the primary subject of research in the area of corporate finance. This study has made a maiden attempt to identify the determinants of capital of structure in Indian context. The results are found to be fairly different from the results of the developed countries in the various aspects as discussed earlier. It is identified that uniqueness and liquidity determine the capital structure of the Indian corporate sector during the period under study. Earning rate, cash flow coverage ratio, size (total assets), growth of assets, non-debt tax 
shield, dividend payout ratio and operating leverage variables are not affecting the capital structure of the Indian corporate sector during study period.

\section{REFERENCES}

[1] Allen, D.E. and Mizuno, H., "The Determinants of Corporate Capital Structure: Japanese Evidence" Applied Economics, Vol. 21, No.5, May, 1989, pp. 569-585.

[2] Anthony, Robert N. and Reece, James S., (1982), "Management Accounting Principles," D.S. Taraporewala and Sons, New Delhi.

[3] Bevan, Alan A. and Danbolt, Jo, "Capital Structure and Its determinants in the UK---- ADecompositional Analysis," Applied Financial Economics, Vol.12, No.3, March, 2002, pp. 159-170.

[4] Bhaduri, Samitra N., "Determinants of Capital Structure Choice: A Study of the Indian Corporate Sector" Applied Financial Economics, Vol. 12, No. 9, Sept., 2002, pp. 655-665.

[5] Bhatt, Rakesh K., "Determinants of Financial Leverage: Some Further Evidence," The Chartered Account, Vol. 29, No. 6, Dec., 1980, pp. 451-56.

[6] Bradley, Jarrell and Kim, "On the Existence of an Optimal Capital Structure: Theory and Evidence," The Journal of Finance, July, 1984, Vol. XXXIX, No. 3, pp. 857-878.

[7] Chandra, Prasanna, (1984), “Financial Management Theory and Practice," Tata McGraw Hill Publishing Company Ltd., New Delhi.

[8] Chandra, Prasanna, (1985), “Management's Guide to Finance and Accounting," Tata McGraw Hill Publishing Company Ltd., New Delhi.

[9] Guthman, Harry G., (Forth Edition), "Analysis of Financial Statements," Prentice Hall of India, New Delhi.

[10] Colombo, Emilio "Determinants of Corporate Capital Structure: Evidence from Hungarian Firms," Applied
Economics, Vol. 33, No.13, Oct., 2001, pp. 1689-1701.

[11] Gangadhar, V. and Begum, Arifa, "Impact of Leverage on Profitability," Journal of Accounting \& Finance, Vol. 17, No.1, Oct., 2002 - March, 2003, pp. 58-72.

[12] Garg, Mahesh Chand and Shekhar, Chander, "Determents of Capital Structure in India," The Management Accountant Vol. 37, No. 2, Feb., 2002, pp. 86-92.

[13] Gupta, Manak C., "The Effect of Size, Growth and Industry on the Financial Structure of Manufacturing Companies," The Journal of Finance, Vol. 24, No. 3, June, 1969, pp. 517-529.

[14] Khan, M.V. \& Jain, P.K., (1983), "Financial Management," Tata McGraw Hill, New Delhi.

[15] Kraus, Alan and Litzenberger, Robert H., "A State Preference Model of Optimal Financial Leverage," The Journal of Finance, Vol. 28, Sept., 1973, pp. 911-921.

[16] Kulkarni, P.V., "Business FinancePrinciples \& Problems," Himalaya Publishing House, Bombay.

[17] Lord, Richard A. and Farr, W.Ken, "Collusion and Financial Leverage: An Analysis of the Integrated Mill Steel Industry," Financial Management, Spring, 2003, pp.127-148.

[18] Mahakud, Jitendra, “Testing the Packing Order Theory of Capital Structure: Evidence from the Indian Corporate Sector", The Icfai Journal of Applied Finance, Vol.12, No. 11, 2006, pp. 17-26.,

[19] Narender and Sharma, "Determinants of Capital Structure in Public Enterprises," Finance, Vol. 12, No. 7, 2006, pp. 14-28.

[20] Ozkan, Aydin, "The Determinants of Corporate Debt Maturity: Evidence from U.K. Firms," Applied Financial Economics, Vol. 12, No. 1, Jan., 2002, pp. 19-24.

[21] Pandey, Dr. Indra Mohan, "Leverage, Risk and the Choice of Capital Structure," The Management Accountant, Vol. 13, No.3, March, 1978, pp. 203-208.

[22] Pandey, Indra Mohan, "Impact of Corporate Debt on the Cost of Equity," 
The Chartered Accountant, Vol. 27, No. I, July, 1978, pp. 14-20.

[23] Pandey, I.M., "The Effect of Liquidity Structure and Leverage on the Cost of Equity of a DFI: A Case Study of ICICI,"The Chartered Accountant, Vol. 28, April, 1979, pp. 922-928.

[24] Pandey, I.M. (2003), “ Management,"Vikas Publishing House, New Delhi.

[25] Pandey, I.M., "The Financial Leverage in India: A Study," Indian Management, March, 1985 pp. 21-34.

[26] Pandey, I.M. Ranjit, Manoj K. and Chotigent, T., "Capital Structure Choices in an Emerging Capital Market: A Case of Thailand," Management \& Change, Vol. 4, No.1, Jan-June, 2000 pp. 1-32.
[27] SaravananPalaisamy, "Ownership Pattern and Debt Equity Choice of Corporates in India: An Empirical Extension," Applied Finance, May, 2006, pp. 29-47.

[28] Taub, Allan J., "Determinants of the Firm's Capital Structure," The Review of Economics and Statistics, Vol. 57, 1975, pp. 410-16.

[29] Titman, S., \&Wessells, R., "The Determinants of Capital Structure Choice," The Journal of Finance, Vol. XLIII, No. 1, March, 1988, pp. 1-19.

[30] Venkatesan, S., "Determinants of Financial Leverage an Empirical Extension," The Chartered Account, Vol. 32, Jan., 1983, pp. 519-27. 